\author{
Urszula Drozdowska \\ Wydział Prawa UwB \\ urszula.drozdowska@wp.pl
}

\title{
Dopuszczalność wykorzystania tzw. opinii prywatnych w cywilnych procesach medycznych - uwagi na tle prawa pacjenta do dokumentacji medycznej
}

\author{
The admissibility of 'private opinions' in the civil medical litigation - remarks under \\ patients' rights to medical documentation
}

\begin{abstract}
A 'private opinion' is a statement of opinion referring to a specific issue made by a privately appointed expert as opposed to an opinion delivered by an expert witness appointed by the court. Consequently, in medical related proceedings a private opinion does not carry the same weight of importance as evidence from an expert witness within the meaning of Article $278 \$ 1$ of the Polish civil code. Nevertheless, the role of private opinion in civil medical litigation is increasing, primarily due to crisis within the institutions of expert witnesses. The author focuses on the issue of whether a private expert has the right of access to information gathered in medical records. Where such expert is appointed by the patient this issue does not raise any doubts because the patient himself holds the right to access those records. The situation becomes problematic when a private expert is appointed by a medical entity to act against a patient and intends to use that patient's medical records as the basis of opinion. The medical entity may process sensitive data contained in medical records but only for purposes strictly defined by law. In view of this dilemma, the author presents the thesis that both the patient and the medical entity have the right to use this evidence, if it is based on medical documentation. Her view is founded on the content of art. $27 \mathrm{sec} .2$ point 5 of the Data Protection Act, which allows the processing of the data necessary to enforce rights before a court and also on referral to the principle of equal treatment in civil proceedings.
\end{abstract}

Keywords: private opinion, expert evidence, access to medical records, the patient's consent

Słowa kluczowe: Opinia prywatna, dowód z opinii biegłego, dostęp do dokumentacji medycznej, zgoda pacjenta 


\section{Wprowadzenie do problematyki}

Przez określenie „proces medyczny” rozumie się postępowanie sądowe, które dotyczy dochodzenia roszczeń odszkodowawczych przez pacjentów w związku z zaistnieniem szkody wyrządzonej przy leczeniu ${ }^{1}$. Oprócz klasycznych spraw, w których zarzuca się popełnienie zawinionego błędu medycznego ${ }^{2}$, pojawiają się sprawy, gdzie źródłem odpowiedzialności cywilnej staje się zakażenie ${ }^{3}$ czy zawinione naruszenie praw pacjenta ${ }^{4}$. Adresatem roszczeń pacjenta jest w tego typu sprawach częściej podmiot leczniczy, rzadziej sam lekarz ${ }^{5}$.

Cechą tych wszystkich postępowań jest złożoność stanu faktycznego i istniejąca w związku z tym konieczność zasięgnięcia opinii biegłych specjalistów. Zarówno wykazanie zdarzenia, z którym powód (pacjent, ewentualnie jego bliscy ${ }^{6}$ ) łączy odpowiedzialność, winy, jak i związku przyczynowego pomiędzy owym zdarzeniem a szkodą wymagają wnioskowania opartego o wiedzę specjalistyczną. Co do zasady, wiedzy tej sądowi dostarczają powołani przezeń biegli, nazywani z tego powodu „pomocnikami organu procesowego"”.

Dowód ten na gruncie przepisów ustawy z dnia 17 listopada 1964 r. - Kodeks Postępowania Cywilnego ${ }^{8}$ nie stanowi środka dowodowego o charakterze pierwszoplanowym ${ }^{9}$, jednak w praktyce orzeczniczej znaczenie jego jest poważne, a w proce-

$1 \quad$ Określenie „proces medyczny” jest stosowane rzadziej niż określenie „proces lekarski”. Oba określenia nie są pojęciami języka prawnego, lecz prawniczego (zob. np. M. Rogowski, Trudności związane z przeprowadzeniem dowodu w procesach lekarskich, (w:) J. Haberko, R.D. Kocyłowski, B. Pawelczyk (red.), Lege artis. Problemy prawa medycznego, Poznań 2008, s. 86 i n.; B. Janiszewska, Aktualne zagadnienia procesów lekarskich (przegląd orzecznictwa), „Prawo i Medycyna” 2004, nr 1, s. 39 i n. Z uwagi na fakt, iż w procesach cywilnych najczęściej pozywany jest podmiot leczniczy, jak się wydaje określenie „proces medyczny” lepiej oddaje istotę zagadnienia. Odmiennie należy przyjąć w sprawach karnych, gdzie zwykle mamy do czynienia z oskarżeniem konkretnego lekarza.

2 Zob. szerzej na temat pojęcia błędu medycznego K. Bączyk-Rozwadowska, Błąd lekarski w świetle doktryny i orzecznictwa sądowego, „Prawo i Medycyna” 2008, nr 3, s. 26 i n.

3 Sprawy dotyczące zakażeń szpitalnych w porównaniu do innych charakteryzują się szczególnymi właściwościami z uwagi na stosowanie domniemań faktycznych, przede wszystkim w zakresie dowodzenia winy i związku przyczynowego. Zob. szerzej B. Janiszewska, Dowodzenie w procesach lekarskich (domniemania faktyczne i dowód prima facie), „Prawo i Medycyna” 2004, nr 2, s. 104 i n.

4 Sprawy dotyczące naruszenia praw pacjenta są coraz częściej na wokandach sądowych. Najsłynniejsze dotyczyły naruszenia prawa pacjentki do informacji o możliwości wykonania badania prenatalnego, zob. np. wyrok SN z dnia 13 października 2005 r., IV CK 161/05, OSP 2006, nr 6, poz. 71 z glosą M. Nesterowicza; wyrok SN z dnia 12 czerwca 2008 r., III CSK 16/08, OSNIC 2009, nr 3, poz. 48.

$5 \quad$ Wynika to przede wszystkim z przyjętej wykładni przepisu art. 430 kc., który przewiduje odpowiedzialność zwierzchnika (tj. podmiotu leczniczego) za zawinione zachowanie podwładnego (tj. lekarza lub innego członka personelu medycznego). W wyroku SN z dnia 26 stycznia 2011 r., IV CSK 308/10, OSP 2011, z. 1, poz. 11 z glosą M. Nesterowicza sąd opowiedział się za koncepcją odpowiedzialności podmiotu leczniczego na podstawie art. 430 kc., niezależnie od istniejącego typu stosunku prawnego pomiędzy podmiotem leczniczym a zatrudnionym w nim lekarzem.

$6 \quad$ Bliscy pacjenta mogą podnosić własne roszczenia odszkodowawcze na podstawie art. 446 kc. w razie śmierci pacjenta.

7 Tak np. NSA w wyroku z dnia 20 sierpnia 1998 r., II SA 992/98, „Monitor Prawniczy” 1999, nr 8, s. 47. W literaturze spotyka się także określenia typu „pomocnik sędziego”, „sędzia naukowy” czy „sędzia faktów”, zob. szerzej K. Piasecki, System dowodów i postępowanie dowodowe w sprawach cywilnych, Warszawa 2010, s. 196. Tekst jedn. z 2016 r. poz. 1822 ze zm. Dalej w skrócie kpc.

$9 \quad$ Formalnie rzecz ujmując na gruncie przepisów procedury cywilnej dowód ten podlega ocenie przez sąd na takich samych zasadach, jak inne dowody w sprawie. Zob. szerzej A. Klich, Dowód z opinii biegłego w postępowaniu cywilnym. Biegły lekarz, Warszawa 2016, s. 16 i n. 
sach medycznych często decyduje o zasądzeniu lub oddaleniu powództwa ${ }^{10}$. Zanim jednak dowód ten zostanie przez sąd dopuszczony, strona inicjująca spór musi przygotować się do procesu. Zgodnie bowiem z art. 6 ustawy z dnia 23 kwietnia 1964 r. - Kodeks Cywilny ${ }^{11}$ ciężar udowodnienia faktów (a zatem w tym wypadku okoliczności warunkujących odpowiedzialność odszkodowawczą) spoczywa na osobie, która z tego tytułu wywodzi skutki prawne ${ }^{12}$. Z kolei przepis art. $232 \mathrm{kpc}$. stanowi, że strony są obowiązane wskazywać dowody dla stwierdzenia faktów, z których wywodzą skutki prawne, a także są obowiązane do przytaczania wszystkich okoliczności faktycznych i dowodów bez zwłoki, aby postępowanie mogło być przeprowadzone sprawnie i szybko (por. art. $6 \$ 2 \mathrm{kpc}$.). Już, więc na samym etapie przygotowań do procesu pojawić się może potrzeba zasięgnięcia opinii specjalisty, która pomoże stronie powodowej wykazać przesłanki odpowiedzialności odszkodowawczej. W takim wypadku mamy do czynienia z prywatną opinią eksperta, ponieważ jest ona sporządzona na zlecenie strony, a nie organu procesowego.

Jak się wskazuje w piśmiennictwie, opinia prywatna odgrywa znaczącą rolę; pozwala ocenić szanse powodzenia powództwa, ułatwia oszacowanie ewentualnych zysków i strat podjęcia postępowania, często decyduje więc o tym, czy batalia sądowa zostanie w ogóle podjęta ${ }^{13}$. W dalszej kolejności, może skłonić strony do zawarcia ugody (przedsądowej lub pozasądowej), w związku z tym może doprowadzić do istotnego skrócenia postępowania dowodowego i szybszego zakończenia postępowania rozpoznawczego ${ }^{14}$. Warto w tym miejscu zaznaczyć, że opinia prywatna może być pomocna nie tylko stronie powodowej, również strona pozwana coraz częściej sięga do tego środka dowodowego, zwłaszcza gdy w toku postępowania zostanie przedstawiona niekorzystna opinia biegłego powołanego przez sąd. Zlecenie sporządzenia opinii prywatnej może w tej sytuacji stanowić przeciwdowód, ułatwić merytoryczną polemikę z przeciwnikiem procesowym. Nie bez znaczenia jest także fakt, że opinia prywatna jest narzędziem istotnie zwiększającym szansę na dotarcie do prawdy, zwłaszcza w przypadkach złożonych i niejednoznacznych, a więc także w sprawach medycznych ${ }^{15}$.

10 Szerzej na temat roli i znaczenia dowodu z opinii biegłego zob. A. Klich, Dowód, op. cit., s. 71.

11 Tekst jedn. z 2017 r. poz. 459 ze zm. Dalej w skrócie kc.

12 Należy wskazać, iż odstępstwem od tej reguły jest przerzucenie ciężaru dowodu z pacjenta na lekarza/podmiot leczniczy wykonania ustawowego obowiązku udzielenia pacjentowi lub jego przedstawicielowi przystępnej informacji, poprzedzającej wyrażenie zgody na zabieg operacyjny, tak SN w wyroku z dnia 17 grudnia 2004 r., II CK 303/04, OSP 2005, nr 11, poz. 131 z glosą aprobującą M. Świderskiej.

13 Zob. szerzej na temat roli i znaczenia opinii prywatnej: K. Knoppek, Prywatna opinia biegłego de lege lata i de lege ferenda, (w:) K. Flaga-Gieruszyńska, G. Jędrejek (red.), Aequitas segitur legem. Księga Jubileuszowa z okazji 75-lecia urodzin profesora Andrzeja Zielińskiego, Warszawa 2014, s. 225 i n.; J. Misztal-Konecka, Znaczenie tzw. opinii prywatnej dla postępowania cywilnego, „Monitor Prawniczy” 2013, nr 2, s. 63 i n.; A. Klich, Dowód, op. cit., s. 77-93; J. Budzowska, Opinia prywatna w sprawie o tzw. błąd medyczny, „Monitor Prawniczy” 2012, nr 5, s. 279 i n.; D. Jagiełło, Dowód z opinii prywatnej w świetle procedury cywilnej oraz karnej, „Themis Polska Nova" 2015, nr 2 (9), s. 153-157.

14 Por. J. Misztal-Konecka, Znaczenie, op. cit., s. 66.

15 Za P. Girdwoyń, T. Tomaszewski, Opinie biegłych w sprawach medycznych na tle zasady kontradyktoryjności, (w:) Prawo wobec problemów społecznych. Księga Jubileuszowa Profesor Eleonory Zielińskiej, Warszawa 2016, s. 627. Chociaż autorzy rozważają problem na tle przepisów procedury karnej, ale jak się wydaje pogląd ten 
Opisując pozytywne aspekty wykorzystania opinii prywatnej w procesach cywilnych, nie wolno zapominać też o pewnym ryzyku z tym związanym ${ }^{16}$. Przede wszystkim wskazuje się, że w dobie istnienia licznych firm odszkodowawczych nastawionych na zysk istnieje ryzyko wydania przez prywatnego eksperta opinii nieprawdziwej, fałszywej. Czynnikiem opiniotwórczym są w tym wypadku pieniądze, w niektórych sprawach pewną rolę mogą odegrać także prezentowane poglądy, zaangażowanie emocjonalne w sprawę, a nawet sugerowanie się przez eksperta treścią udostępnionych informacji i dokumentów ${ }^{17}$. Dobrze wszak znane jest, zarówno prawnikom, jak i lekarzom, zjawisko selekcjonowania informacji i przekazywania tylko tych, które świadczą na korzyść przekazującego. Ponadto w przypadku procesów medycznych ekspert prywatny może nie mieć wglądu do pełnej dokumentacji medycznej, którą w procesie będzie dysponował sąd ${ }^{18}$.

W związku z tym ostatnim zagadnieniem pojawia się interesujący problem dotyczący tego, czy ekspert prywatny ma prawo dostępu do informacji zgromadzonych w dokumentacji medycznej. W przypadku wyrażenia zgody przez samego pacjenta jako dysponenta prawa do dokumentacji medycznej - zagadnienie to nie budzi większych wątpliwości. Ekspert na podstawie udzielonego mu upoważnienia ma prawo zapoznać się z dokumentacją medyczną pacjenta. Sytuacja przedstawia się odmiennie, gdy to podmiot leczniczy, jako przeciwnik procesowy pacjenta zamierza wykorzystać posiadaną dokumentację medyczną w celu sporządzenia prywatnej opinii. Podmiot leczniczy może bowiem przetwarzać dane sensytywne zawarte w dokumentacji medycznej w celach ściśle określonych przez prawo.

Biorąc powyższe pod uwagę, problematyka wykorzystania prywatnych opinii biegłych w medycznym procesie cywilnym jest zagadnieniem, które warto poddać bliższej analizie. W pierwszej kolejności wyjaśnieniu podlegać będzie charakter prawny opinii prywatnej w porównaniu do dowodu $\mathrm{z}$ opinii biegłego $\mathrm{w}$ rozumieniu art. 278 i n. kpc. Następnie opisania wymaga kwestia wykorzystania tego środka dowodowego przez obie strony sporu sądowego, w kontekście prawa pacjenta do dokumentacji medycznej.

\section{Charakter prawny opinii prywatnej w świetle poglądów doktryny procesu cywilnego i orzecznictwa sądowego}

W myśl dominującego poglądu nauki, opinią prywatną jest każde oświadczenie, powołujące się na wiadomości specjalne, niepochodzące od biegłego powołanego

można odnieść do przepisów procedury cywilnej, która chociaż hołduje zasadzie kontradyktoryjności sporu zdecydowanie silniej niż procedura karna, ale także wyraża zasadę dążenia do prawdy materialnej.

16 Zob. np. rozważania A. Klich z punktu widzenia procesu cywilnego, A. Klich, Dowód, op. cit., s. 91 i n.

17 Zob. A. Szymańska, Wykorzystanie prywatnej ekspertyzy w postępowaniu karnym, „Studenckie Zeszyty Naukowe" 2014, nr 25, s. 93.

18 Tak J. Budzowska, Opinia prywatna, op. cit., s. 279-280. 
przez sąd ${ }^{19}$. Innymi słowy jest to wynik pracy rzeczoznawcy, który swoją ekspertyzę wykonuje na zlecenie stron, nie zaś na zlecenie organu procesowego, stąd inne jej określenia, takie jak: opinia pozaprocesowa, pozasądowa czy rzeczoznawcza ${ }^{20}$.

W literaturze od dawna dyskutowana jest kwestia charakteru prawnego opinii prywatnej, zwłaszcza że w świetle przepisów ustawy procesowej nie może być ona potraktowana jako dowód z opinii biegłego w rozumieniu art. 278 kpc. ${ }^{21}$ Należy podkreślić, iż dowód z opinii biegłego może zaistnieć w procesie cywilnym wyłącznie na polecenie sądu, wtedy gdy zachodzi potrzeba skorzystania $z$ wiadomości specjalnych i co do zasady, gdy został złożony stosowny wniosek procesowy ${ }^{22}$. Inne są zatem przesłanki uzasadniające sporządzenie opinii sądowej, inne zaś opinii prywatnej.

Pozycja biegłego powołanego przez sąd w postępowaniu cywilnym jest wyjątkowa ${ }^{23}$. Przepisy procedury cywilnej mają za zadanie zapewnić bezstronność biegłemu. Temu celowi służy m.in. instytucja wyłączenia biegłego. Aż do ukończenia czynności przez biegłego, strona może żądać jego wyłączenia z przyczyn, z jakich można żądać wyłączenia sędziego ${ }^{24}$. Zgodnie z art. 281 zd. 2 kpc., gdy strona zgłasza wniosek o wyłączenie biegłego po rozpoczęciu przez niego czynności, obowiązana jest uprawdopodobnić, że przyczyna wyłączenia powstała później lub że przedtem nie była jej znana. Bezstronność ma zapewnić także składane przez biegłego przyrzeczenie. Jego treść brzmi następująco: „Świadomy znaczenia mych słów i odpowiedzialności przed prawem przyrzekam uroczyście, że powierzone mi obowiązki biegłego wykonam z całą sumiennością i bezstronnością"25. Przyrzeczenie jest skła-

19 Zob. J. Misztal-Konecka, Znaczenie, op. cit., s. 64; K. Woźniewski, Tzw. prywatne opinie biegłych, „Gdańskie Studia Prawnicze - Przegląd Orzecznictwa" 2005, nr 3, s. 92 i n.

20 Identyczne definicje dotyczące opinii prywatnych są tworzone na gruncie postępowania karnego; zob. Z Kwiatkowski, Dopuszczalność wykorzystania „opinii prywatnej” w procesie karnym, (w:) A. Przyborowska-Klimczak, A. Taracha (red.), ludicum et scientia. Księga Jubileuszowa Profesora Romualda Kmieciaka, Warszawa 2001, s. 570; A. Podemska, Opinia biegłego w nowym modelu postępowania karnego, „Zeszyty Naukowe Towarzystwa Doktorantów UJ. Nauki Społeczne" 2014, nr 8, s. 39 i n.

21 Zob. szerzej J. Misztal-Konecka, Znaczenie, op. cit., s. 63-65 oraz powołaną przez nią literaturę i orzecznictwo.

22 Sąd dopuszcza dowód z opinii biegłego po wysłuchaniu wniosków obu stron w tym przedmiocie (art. $293 \S 1$ kpc.). Może dopuścić dowód z opinii biegłego z urzędu w trybie art. 232 zd. 2 kpc., gdy przeprowadzenie tego dowodu stanowi jedyny sposób przeciwdziałania niebezpieczeństwu oczywiście nieprawidłowego rozstrzygnięcia sprawy, podważającego funkcję procesu cywilnego, tak SN w wyroku z dnia 15 stycznia 2010 r., I CSK 199/09, Lex nr 570114, zob. też wyrok SN z dnia 7 marca 2013 r., II CSK 422/12, Lex nr 1314390, w którym sąd wskazał, iż dowód z opinii biegłego ze względu na składnik w postaci wiadomości specjalnych jest dowodem tego rodzaju, że nie może być zastąpiony inną czynnością dowodową, np. przesłuchaniem świadka. Sąd dopuszcza się naruszenia art. 232 zdanie drugie kpc., skoro z urzędu nie przeprowadza dowodu z opinii biegłego, niezbędnego dla właściwej oceny zasadności wytoczonego powództwa.

23 Zob. szerzej A. Klich, Dowód, op. cit., s. 103 i n.

24 Zob. art. 48 i 49 kpc. Zadaniem organu procesowego jest sprawdzenie, czy nie zachodzą okoliczności wyłączające biegłego od udziału w sprawie. Z tego względu przepisy kpc. przewidują przed powołaniem biegłego wysłuchanie stron. Sam biegły powinien także poinformować sąd o przyczynie jego wyłączenia, np. wtedy gdy sporządził uprzednio opinię prywatną. Zob. szerzej J. Misztal-Konecka, op. cit., s. 67-68. Należy zgodzić się z argumentacją tej autorki, iż wydanie opinii prywatnej powinno stanowić przesłankę do wyłączenia od opiniowania (podobnie Sąd Apelacyjny we Wrocławiu w wyroku z dnia 16 kwietnia 2012 r., II AKA 67/12, OSAW 2013, nr 3, poz. 294). Problematyczna jest przyczyna wyłączenia w sytuacji, gdy biegły uprzednio leczył pacjenta. W wyroku z dnia 8 czerwca 2010 r. (II UK 399/09) SN przyjął, że nie stanowi to okoliczności, która mogłaby wywołać wątpliwość, co do bezstronności biegłego. Krytycznie wobec tego orzeczenia A. Klich, Dowód, op. cit., s. 85.

25 Zwróćmy uwagę na fakt, iż w treści przyrzeczenia nie ma zobowiązania mówienia prawdy (jak np. w przyrzeczeniu odnoszącym się do świadka w art. 268 kpc.), tym niemniej wskazuje się, iż sąd może zwrócić biegłemu na to 
dane, jeśli strony (art. $283 \$ 1 \mathrm{kpc}$.) lub sąd (art. 515 kpc.) inaczej nie zdecydują. Przyrzeczenie składa biegły powołany w konkretnej sprawie (biegły ad hoc), biegły sądowy stały składa przyrzeczenie przy objęciu stanowiska i wpisaniu go na listę biegłych sądowych. Sąd w postanowieniu o dopuszczeniu dowodu z opinii biegłego określa zarówno osobę biegłego (ewentualnie wskazuje kilku biegłych), zakres materiału będącego przedmiotem opinii, jak też definiuje merytoryczny zakres opiniowania, zwykle przedstawiając pewne tezy, które mają być stwierdzone i ocenione za pomocą wiadomości specjalnych ${ }^{26}$.

Opinia prywatna pozbawiona jest wskazanych wyżej gwarancji formalnych i w związku z tym nie może zostać zrównana z opinią biegłego. Warto wskazać, że $\mathrm{w}$ orzecznictwie ugruntowany jest pogląd, iż oparcie wyroku na pozasądowym oświadczeniu biegłego stanowi uchybienie procesowe uzasadniające możliwość podniesienia skutecznego zarzutu apelacyjnego ${ }^{27}$. Nie powinno zatem dojść do sytuacji zastępowania dowodu z opinii biegłego dowodem z prywatnej opinii, choćby została ona sporządzona przez osobę wpisaną na listę biegłych ${ }^{28}$. Co więcej, w literaturze przedmiotu podkreśla się, że biegły odgrywa pomocniczą rolę względem sądu i jest uprawniony do używania tytułu biegłego sądowego tylko w razie sporządzenia opinii na zlecenie określonego w przepisach kręgu podmiotów (tj. sądu), działanie biegłego poza zakresem jego kompetencji może skutkować nawet skreśleniem z listy biegłych sądowych ${ }^{29}$.

Wyrażone wyżej poglądy nie przekreślają jednak znaczenia opinii prywatnych. W wyroku SN z dnia 8 czerwca 2001 r. $^{30}$ został wyrażony pogląd, iż ekspertyza pozasądowa może być potraktowana jako część argumentacji strony. Dzieje się tak w sytuacji, gdy strona wyraźnie wnosi o potraktowanie ekspertyzy jako części własnej argumentacji faktycznej i prawnej. Jeżeli jednak strona składa pozasądową eksper-

uwagę, zwłaszcza, że przed złożeniem przyrzeczenia należy uprzedzić biegłego o odpowiedzialności karnej za złożenie fałszywej opinii (art. 233 § 4 k.k.).

26 W wyroku z dnia 11 lipca 1969 r., I CR 140/69, OSNP 1970, nr 5, poz. 85, SN stwierdził, iż zadaniem biegłego nie jest jednak ustalenie stanu faktycznego sprawy, lecz naświetlenie i wyjaśnienie przed sądem okoliczności z punktu widzenia posiadanych przez niego wiadomości specjalnych, przy uwzględnieniu zebranego i udostępnionego biegłemu materiału sprawy.

27 Tak SN w wyroku z dnia 29 września 1956 r., III CR 121/56, OSN 1958, nr 1, poz. 16. Pogląd ten jest nadal aktualny z tym zastrzeżeniem, iż na gruncie obecnie obowiązujących przepisów procedury cywilnej należy złożyć zastrzeżenie w trybie art. $162 \mathrm{kpc}$., a zarzut apelacyjny powiązać z art. $233 \mathrm{kpc}$. Zob. też wyrok SN z dnia 8 czerwca 2001 r., I PKN 458/00, OSNP 2003, nr 11, poz. 112, teza II, gdzie czytamy: „Pozasądowa ekspertyza rzeczoznawczy sporządzona na zlecenie strony nie podlega ocenie sądu jako dowód z opinii biegłego (art. 278 kpc.)”.

Tak SN w cytowanym już wyroku z dnia 29 września 1956 r., III CR 121/56. , OSN 1958, nr 1, poz. 16: „Nie może być traktowana jako dowód w procesie opinia biegłego, choćby nim był stały biegły sądowy, sporządzona na piśmie na polecenie strony i złożona do akt sądowych". Zob. też wyrok SN z dnia 12 kwietnia 2002 r., I CKN 92/00, OSG 2003, nr 11, poz. 112: „Uznanie opinii biegłego, choćby był nim biegły sądowy, będącej dokumentem prywatnym, narusza art. 233 kpc.”.

29 Zob. A. Klich, Dowód, op. cit., s. 81, 217. Jak się wydaje, nie chodzi tu o zakaz sporządzania opinii prywatnych przez biegłych wpisanych na listę, ale o nieposługiwanie się tytułem „biegły sądowy” w razie sporządzenia tego typu opinii, po to, aby nie wprowadzić strony procesowej w błąd co do znaczenia (rangi) wydanej w ten sposób opinii. 
tyzę z wyraźną intencją potraktowania jej jako dowodu w sprawie, wówczas istnieją podstawy do przypisania jej rangi dowodu $z$ dokumentu prywatnego ${ }^{31}$.

Zgodnie z art. 245 kpc. dokument prywatny stanowi dowód tego, że osoba, która go podpisała, złożyła oświadczenie zawarte w tym dokumencie. Treść oświadczenia biegłego zawarta w dokumencie prywatnym nie jest objęta domniemaniem zgodności z prawdą, co oznacza że osoba mająca w tym interes prawny może dowodzić, iż treść złożonych oświadczeń nie odpowiada stanowi rzeczywistemu ${ }^{32}$. W ten sposób strony wdają się w spór merytoryczny dotyczący twierdzeń i tez zawartych w opinii (por. treść art. $253 \mathrm{kpc}^{33}$ ). Warto podkreślić, że gromadzenie materiału procesowego, tj. twierdzeń faktycznych i służących sprawdzeniu twierdzeń środków dowodowych w warunkach polskiego procesu cywilnego - należy do stron procesowych (zasada kontradyktoryjności sporu). Dla procesu typu kontradyktoryjnego charakterystyczna jest kategoria ciężarów procesowych, a w szczególności ciężaru twierdzenia i ciężaru udowodnienia. Jakkolwiek daleko jesteśmy od modelu postępowania, w którym typowym elementem kontradyktoryjności sporu jest instytucja „biegłego strony”, tak można twierdzić, iż potraktowanie opinii prywatnej jako dokumentu prywatnego jest krokiem w kierunku zwiększenia kontradyktoryjności sporu. Problem polega jednak na tym, iż biegły prywatny nie może być wysłuchany w charakterze biegłego, ponieważ biegłym sądowym nie jest.

Sąd Najwyższy w wyroku z dnia 8 listopada 1976 r. ${ }^{34}$ wskazał, iż osoba, która $z$ racji posiadania wiadomości specjalnych ma spostrzeżenia niedostępne dla innych osób (np. lekarz leczący chorego), powinna być z reguły przesłuchana w charakterze świadka, a funkcje biegłego należy powierzyć innej osobie, która $\mathrm{z}$ faktami istotnymi dla rozstrzygnięcia sprawy poprzednio się nie zetknęła ${ }^{35}$. Zakładając więc możliwość przesłuchania prywatnego eksperta w charakterze świadka, należy zaakcentować różnice pomiędzy dowodem $\mathrm{z}$ opinii biegłego a dowodem z zeznań świadka. Podstawowa różnica sprowadza się do tego, że świadkowie komunikują wiadomości o faktach i stanach rzeczy, a biegli wypowiadają swoje zdanie o faktach, czyli opinię. Jedynie wyjątkowo przedmiotem dowodu z opinii biegłego mogą być informacje natury faktycznej ${ }^{36}$. W związku z powyższym, składając wniosek o dopuszczenie dowodu z zeznań świadka, tj. biegłego prywatnego, musimy wykazać, że nasz ekspert przedstawi przed sądem informacje faktyczne spostrzeżone przez niego dzięki do-

31 Podobnie w wyroku SN z dnia 15 stycznia 2010 r., I CSK 199/09, Lex nr 570114, w wyroku z dnia 8 czerwca 2010 r., I PKN 468/00, Lex nr 50484; wyrok SN z dnia 25 lutego 2015 r., IV CSK 312/14, Legalis.

32 Zob. wyrok SN z dnia 2 lipca 2009 r., V CSK 4/09, Lex nr 527176.

33 Zob. wyrok SN z dnia 2 lutego 2011 r., II CSK 323/10, Lex nr 738542. „Do prywatnej opinii przedstawionej przez stronę w toku procesu stosuje się art. 253 kpc.".

34 Sygn. ICR 374/76, OSN 1977, nr 10, poz. 187.

35 Polskie prawo procesowe nie przewiduje instytucji „świadków-biegłych” znanej prawu niemieckiemu i austriackiemu, zob. szerzej K. Gajda-Roszczynialska, (w:) Ł. Błaszczyk, K. Markiewicz (red.), Dowody i postępowanie dowodowe w sprawach cywilnych. Komentarz praktyczny z orzecznictwem, Warszawa 2015, s. 646-647.

36 Ibidem, s. 646. Zob. też A. Klich, Lekarz jako osobowe źródło dowodowe w postępowaniu cywilnym (część I - lekarz jako świadek), „Prawo i Medycyna” 2013, nr 3-4, s. 120-136. 
świadczeniu zawodowemu, a nie tylko wyrazi swoją opinię (ta bowiem już znajduje się w aktach sprawy). Istnieje więc ryzyko, iż sąd nie przychyli się do naszego wniosku i polemika będzie możliwa jedynie za pomocą pism procesowych. W judykaturze wyrażono jednak trafny pogląd, że prywatna ekspertyza może stanowić przesłankę przemawiającą za koniecznością dopuszczenia przez sąd dowodu z opinii innego biegłego lub opinii uzupełniającej ${ }^{37}$. Co więcej, jeżeli powołany przez sąd biegły opinię pozasądową kwestionuje - rzeczą sądu jest krytyczne rozważenie argumentacji obu opinii ${ }^{38}$.

Sąd Najwyższy w wyroku z dnia 2 lutego $2011 \mathrm{r}^{39}$ stwierdził, iż przedstawianie przez strony prywatnych opinii jest coraz częstszym zjawiskiem procesowym. Stanowią one element materiału procesowego i jako takie powinny być udostępnione stronie przeciwnej. W wyroku z dnia 30 czerwca $2004 \mathrm{r}^{40} \mathrm{SN}$ stwierdził, iż dowód $\mathrm{z}$ dokumentu prywatnego jest samodzielnym środkiem dowodowym, którego moc sąd ocenia stosownie do zasady swobodnej oceny dowodów wyrażonej w art. 233 $\$ 1 \mathrm{kpc}$., tj. według własnego przekonania, na podstawie wszechstronnego rozważenia zebranego materiału w sprawie. W związku z tym, tak, jak w przypadku innych dowodów ocenie podlega to, czy opinia prywatna zasługuje na uznanie. Wynikiem oceny sądu może być przyznanie lub odmowa dowodowi z dokumentu waloru wiarygodności.

W sprawie rozpatrywanej przez Sąd Apelacyjny w Szczecinie ${ }^{41}$ sądy odmówiły wiarygodności prywatnym ekspertyzom lekarskim przez to, że zostały sporządzone przez lekarzy o zupełnie odmiennej specjalności w stosunku do przedmiotu podlegającego opiniowaniu specjalistycznemu, co już samo w sobie pozbawiało je wartości z punktu widzenia oceny okoliczności istotnych dla rozstrzygnięcia sprawy. Ponadto osoby opiniujące nie dysponowały pełną dokumentacją zgromadzoną w toku procesu. Sąd Apelacyjny w związku z tym stwierdził, że opinie te niewiele wniosły do sprawy, albowiem jak wynika z ich treści jednoznaczna ocena stanu zdrowia powódki okazała się niemożliwa z uwagi na niepełną dokumentację medyczną, jaką dysponował sporządzający opinię.

Z kolei w sprawie rozpatrywanej przez Sąd Apelacyjny w Katowicach ${ }^{42}$, sąd pierwszej instancji (Sąd Okręgowy) dopuścił w charakterze dowodu z opinii biegłego prywatną opinię przedstawioną przez pozwanego. W związku z czym trafny okazał się zarzut podniesiony $\mathrm{w}$ apelacji przez stronę przeciwną naruszenia przez sąd art. $278 \$ 1 \mathrm{kpc}$. Jednakże naruszenie to nie miało - zdaniem Sądu Apelacyjnego -

Por. wyrok SN z dnia 21 sierpnia 2008 r., IV CSK 168/2008, „Monitor Prawniczy” 2008, nr 18, s. 954. Tak SN w wyroku z dnia 8 listopada 1988 r., II CR 312/88, Legalis.

Sygn. II CSK 323/10, Lex nr 738542.

Sygn. IV CK 474/03, OSNC 2005, nr 6, poz. 113; wyrok SN z dnia 10 października 2012 r., I UK 210/12, Lex $\mathrm{nr} 1284721$.

41 Wyrok SA w Szczecinie z dnia 4 grudnia 2012 r., I ACa 119/12, Lex nr 1246842.

42 IACa 676/12, Lex nr 1236712.
} 
Dopuszczalność wykorzystania tzw. opinii prywatnych w cywilnych procesach...

wpływu na sposób rozstrzygnięcia sprawy, ponieważ opinia prywatna korespondowała z ustaleniami poczynionymi przez biegłych sądowych.

\section{Dopuszczalność wykorzystania opinii prywatnej w świetle prawa pacjenta do dokumentacji medycznej}

Zgodnie z art. 24 ust. 1 ustawy z dnia 6 listopada 2008 r. o prawach pacjenta i Rzeczniku Praw Pacjenta ${ }^{43}$ podmiot udzielający świadczeń zdrowotnych jest obowiązany prowadzić, przechowywać i udostępniać dokumentację medyczną w sposób określony w tej ustawie oraz w ustawie z dnia 28 kwietnia 2011 r. o systemie informacji w ochronie zdrowia ${ }^{44}$, a także zapewnić ochronę danych zawartych $w$ tej dokumentacji. Prawo dostępu do dokumentacji medycznej jest częścią szeroko rozumianej autonomii informacyjnej pacjenta, w związku z tym ustawodawca w pierwszej kolejności wymienia jako uprawnionego samego pacjenta, jego przedstawiciela ustawowego oraz osoby przez te podmioty upoważnione (zob. art. 26 ust. 1 u.p.p.). Nie oznacza to jednak, że inne podmioty prawa nie mają - bez zgody pacjenta - dostępu do dokumentacji medycznej ${ }^{45}$. Zgodnie z art. 26 ust. 3 u.p.p. są to m.in. podmioty udzielające świadczeń zdrowotnych, jeżeli dokumentacja ta jest niezbędna do zapewnienia ciągłości świadczeń zdrowotnych; organy władzy publicznej, NFZ, organy samorządu zawodów medycznych, konsultanci krajowi i wojewódzcy, w zakresie niezbędnym do wykonywania przez te podmioty ich zadań, w szczególności kontroli i nadzoru; podmioty, o których mowa w art. 119 ust. 1 i 2 ustawy z dnia 15 kwietnia 2011 r. o działalności leczniczej ${ }^{46}$, w zakresie niezbędnym do przeprowadzenia kontroli na zlecenie ministra właściwego do spraw zdrowia, itd. W każdym z opisywanych przypadków udostępnienia dokumentacji zwraca uwagę okoliczność, że ustawodawca określa powód przetwarzania informacji zawartych w dokumentacji; jedyny wyjątek w tym zakresie dotyczy zakładów ubezpieczeń, które mają dostęp do dokumentacji za zgodą ubezpieczonego pacjenta (por. art. 26 ust. 3 pkt 7 u.p.p. ${ }^{47}$ ). Ten sposób regulacji podyktowany jest potrzebą ochrony danych wrażliwych, do których niewątpliwie należą dane zawarte w dokumentacji medycznej. Zgodnie z art. 27 ust. 1 ustawy z dnia 29 sierpnia 1997 r. o ochronie danych osobowych ${ }^{48}$ przetwarza- $^{-}$

\footnotetext{
43 Tekst jedn. Dz.U. z 2016 r. poz. 186 ze zm. Dalej w skrócie u.p.p. lub ustawa o prawach pacjenta.

44 Tekst jedn. Dz.U. z 2015 r. poz. 636 ze zm.

45 Problem tego, kto jest dysponentem informacji zgromadzonych w dokumentacji, został rozwiązany przez ustawodawcę w specyficzny sposób. Ponieważ dokumentacja medyczna nie służy wyłącznie leczeniu pacjenta, ale podlega reglamentacji publicznoprawnej, tj. kontroli i nadzorowi, w związku z tym jej dysponentem jest podmiot przetwarzający dokumentację.

46 Tekst jedn. Dz.U. z 2016 r., poz. 1638 ze zm.

47 Tym niemniej ustawodawca w ustawie z dnia 11 września 2015 r. o działalności ubezpieczeniowej i reasekuracyjnej (Dz.U. z 2015 r., poz. 1844 ze zm.) przewidział surowsze przesłanki związane z wykorzystaniem dokumentacji medycznej ubezpieczonego pacjenta przez ubezpieczyciela. Tekst jedn. Dz.U. z 2015 r., poz. 2135 ze zm. Dalej w skrócie u.o.d.o.
} 
nie danych wrażliwych jest zabronione, a wyjątki od tej zasady, określone w ustępie 2 art. 27, powinny być ściśle interpretowane.

Cytowany przypadek udostępniania dokumentacji innym podmiotom udzielającym świadczeń jest $\mathrm{w}$ ustawie o prawach pacjenta dookreślony celem $\mathrm{w}$ postaci zapewnienia ciągłości udzielania świadczeń. W piśmiennictwie z zakresu prawa medycznego wskazuje się, że rozwiązanie to koresponduje $\mathrm{z}$ innymi przepisami prawa medycznego, które przewidują analogiczne dyspensy od tajemnicy medycznej (por. np. art. 14 ust. 2 pkt 4 u.p.p.) i jest podyktowane dobrem pacjenta ${ }^{49}$. W celu poprawnego wykonania czynności leczniczych podmiot udzielający świadczeń powinien dysponować określonymi informacjami medycznymi. Z uwagi na ochronę prywatności pacjenta, wykładnia tego przepisu powinna być rygorystyczna, a to oznacza, że profesjonalista medyczny domagający się dostępu powinien uzasadnić okoliczności wskazujące na tę potrzebę oraz zakres oczekiwanych danych ${ }^{50}$. W związku z powyższym nie powinno budzić wątpliwości twierdzenie, że nie można w cytowanym unormowaniu znaleźć usprawiedliwienia dla udostępnienia dokumentacji medycznej lekarzowi specjaliście, który na potrzeby jednej ze stron procesu cywilnego sporządza opinię prywatną.

Problem dotyczący przetwarzania dokumentacji medycznej przez podmiot nią administrujący jest dostrzegany w praktyce stosowania prawa. W swoim opracowaniu, skierowanym do podmiotów wykonujących działalność leczniczą A. Sieńko wskazuje, że w przypadku zgłoszenia roszczenia przez pacjenta podmiot leczniczy jest zobowiązany zawiadomić ubezpieczyciela udzielającego ochrony ubezpieczeniowej w okresie, w którym realizowano objęte roszczeniem świadczenie ${ }^{51}$. Zakład ubezpieczeń, podejmując tzw. postępowanie likwidacyjne, ocenia roszczenia pacjenta przez własnego konsultanta medycznego, w związku z tym zwraca się do podmiotu wykonującego działalność leczniczą (ubezpieczonego z tytułu odpowiedzialności cywilnej) o udzielenie wyjaśnień. Na tym więc już etapie zasadne, a nawet konieczne jest udostępnienie ubezpieczycielowi dokumentacji medycznej pacjenta ${ }^{52}$. Tymczasem bez dysponowania jego zgodą, podmiot udzielający świadczeń nie może tego uczynić. Jakkolwiek pacjenci na tym etapie często wyrażają zgodę na udostępnienie dokumentacji (licząc zapewne na to, że ubezpieczyciel od odpowiedzialności cywilnej podmiotu leczniczego - bez wszczęcia procesu cywilnego - wypłaci żądane świadczenia), tak już na etapie trwającego procesu, uważając ubezpieczyciela czy

Zob. R. Kubiak, Tajemnica medyczna, Warszawa 2016, s. 224; U. Drozdowska, E. Kowalewska-Borys, W. Wojtal, Udostępnienie, przechowywanie i niszczenie dokumentacji medycznej, (w:) U. Drozdowska (red.), Dokumentacja medyczna, Warszawa 2012, s. 67. 50 Na marginesie należy zaznaczyć, że kwestia ochrony prywatności pacjenta w kontaktach $z$ wieloma przedstawiprzez świadczeniodawców elektronicznej dokumentacji medycznej i obowiązku przesyłania jednostkowych danych medycznych do określonych platform stworzonych w ramach Systemu Informacji Medycznej.

51 A. Sieńko, Błędy medyczne, odpowiedzialność lekarza i placówki medycznej. Jak uniknąć kosztownych pułapek, Warszawa 2013, wyd. 2, s. 70. 
prywatnego konsultanta leczniczego za działających na rzecz pozwanego (a zatem za adwersarza procesowego), często zgody swej odmawiają.

W związku z powyższym podstawy udostępnienia dokumentacji medycznej (bez zgody pacjenta) poszukuje się w treści cytowanego art. 27 ust. 2, który w punkcie 5 przewiduje możliwość przetwarzania danych, jeśli dotyczy to danych, które są niezbędne do dochodzenia praw przed sądem. Zdaniem P. Barty i P. Litwińskiego, przesłanka ta legalizuje przetwarzanie danych wrażliwych w zakresie czynności związanych z dochodzeniem wszelkich praw (prywatnych i publicznych), które są realizowane przez sądy, strony i ich pełnomocników, bez względu na rodzaj i tryb postępowania $^{53}$.

Na temat dopuszczalności zastosowania wymienionego unormowania w procesie cywilnym wypowiedział się Sąd Apelacyjny w Krakowie w wyroku z dnia 3 września 2015 r. ${ }^{54}$ Okoliczności sprawy były następujące. Pozwany podmiot leczniczy w związku z toczącym się procesem o odszkodowanie i zadośćuczynienie z tytułu błędu medycznego wystąpił o wydanie prywatnej opinii dotyczącej czynności podejmowanych przez personel medyczny w czasie pobytu powódki w szpitalu, związanego z jej ciążą zakończoną urodzeniem dziecka. W związku z powyższym udostępnił dokumentację medyczną powódki w celach konsultacyjnych. Warto nadmienić, że w sprawie tej została wydana niekorzystna dla pozwanego opinia biegłego powołanego przez sąd, a wniosek pozwanego o dopuszczenie dowodu z uzupełniającej opinii innego biegłego, z uwagi na wyjaśnienie istotnych okoliczności sprawy, został przez sąd oddalony. Powódka wytoczyła następny proces pozwanemu, żądając w imieniu własnym i dziecka przeprosin oraz zadośćuczynienia z tytułu naruszenia dóbr osobistych. Twierdziła, że gdy dowiedziała się o udostępnieniu dokumentacji medycznej dotyczącej jej osoby oraz jej syna lekarzowi opiniującemu na zlecenie pozwanego szpitala, była oburzona. Odczuwała dyskomfort, mając świadomość, że intymne informacje o stanie jej zdrowia i nowo narodzonego przez nią dziecka „wyciekły”.

Sądy rozpatrujące tę sprawę przyjęły odmienną argumentację, jakkolwiek w obu wyrokach uznano roszczenia powodów za bezzasadne ${ }^{55}$. Sąd okręgowy, jako sąd I instancji oddalił powództwo z powołaniem się na art. 27 ust. 2 pkt 5 u.o.d.o. Sąd ten uznał, że cytowany przepis należy odnieść do wszystkich stron procesowych, chodzi tu zarówno o występowanie z roszczeniami, z oskarżeniem, jak i o obronę praw. W związku z tym podmiot leczniczy był uprawniony w zakresie przetwarzania danych zawartych w dokumentacji medycznej. Sąd wskazał, że na pozwanym ciążył obowiązek wykazania, iż jego działanie nie było bezprawne i ten obowiązek został

\footnotetext{
53 P. Barta, P. Litwiński, Ustawa o ochronie danych osobowych. Komentarz, Warszawa 2015, wyd. 3, s. 315.

54 IACa 679/15, Lex nr 1927548.

55 SO oddalił roszczenia z uwagi na wykazanie przesłanki działania zgodnego z prawem przez podmiot leczniczy, SA zaś odmówił zasądzenia roszczeń, ponieważ naruszenie dóbr osobistych powódki nie łączyło się w powszechnym odczuciu ze złamaniem tajemnicy lekarskiej, w sposób godzący w jej dobra osobiste. Zob. uzasadnienie cytowanego wyroku.
} 
zrealizowany zgodnie z treścią art. 24 kc. Zakres materiałów przekazanych specjaliście był uzasadniony treścią opinii, jaka miała zostać wydana, a tym samym adekwatny do celu, jakiemu miała ta opinia służyć. Trudno bowiem wymagać, aby z dokumentów zostały usunięte dane dotyczące choćby stanu zdrowia powodów w sytuacji, gdy przedmiotem opinii miała być prawidłowość podejmowanych przez personel medyczny czynności adekwatnie do stanu, w jakim powódka znajdowała się przed porodem i czynności związanych z porodem. Okoliczności te były istotne dla rozstrzygnięcia toczącej się między stronami sprawy o zapłatę odszkodowania i ustalenie odpowiedzialności na przyszłość. Ponadto pozwany podjął kroki celem zanonimizowania przekazywanej dokumentacji ${ }^{56}$.

Odmiennie Sąd Apelacyjny, przyjął on, że udostępnienie kolejnemu lekarzowi dokumentacji medycznej w celach konsultacyjnych stanowi o naruszeniu dóbr osobistych powodów. Sąd ten argumentował, że przepisy prawa medycznego, jako zapewniające dalej idącą ochronę mają pierwszeństwo przed przepisami u.o.d.o. Podnoszony argument podmiotu leczniczego, że realizował on swoje własne prawo do obrony nie zasługiwał, według sądu, na uwzględnienie, dlatego, że przedstawienie opinii prywatnej nie ma waloru dowodowego, a jedynie stanowi rozwinięcie własnych twierdzeń i zarzutów strony w prowadzonym procesie. Zdaniem sądu, nie doszło więc do wyłączenia bezprawności, ponieważ udostępnienie dokumentacji może nastąpić na mocy postanowienia sądu dopuszczającego dowód z opinii biegłego i tylko w tym celu może być wydana dokumentacja. Strona może wystąpić z tego typu wnioskiem dowodowym, nie ma zaś swobody w zakresie przetwarzania dokumentacji medycznej.

Odnosząc się do argumentacji zawartej w prezentowanych orzeczeniach, warto zwrócić uwagę na dwa zagadnienia. Pierwsze, związane jest z relacją przepisów u.o.d.o. do tzw. ustaw sektorowych, tj. w tym wypadku ustawy o prawach pacjenta, drugie bezpośrednio odnosi się do opinii prywatnej jako środka dowodowego w procesie medycznym.

Pierwsze zagadnienie jest źródłem wielu wątpliwości doktrynalnych ${ }^{57}$, ponieważ art. 5 u.o.d.o., który określa wzajemne relacje pomiędzy u.o.d.o. a przepisami tzw. ustaw sektorowych, nie jest typową normą kolizyjną ${ }^{58}$. Zgodnie z tym przepisem, jeśli przepisy odrębnych ustaw, które odnoszą się do przetwarzania danych, przewidują dalej idącą ochronę, niż to wynika z niniejszej ustawy, stosuje się przepisy tych ustaw.

56 
W związku z powyższym u.o.d.o. ma charakter subsydiarny, a jej regulacje powinno się brać pod uwagę, pod kątem zapewnienia tzw. minimum ochronnego ${ }^{59}$.

Warto zauważyć, że przyjmuje się tu założenie, iż ustawy szczególne dotyczące przetwarzania danych będą uzupełniać lub rozwijać obowiązki w zakresie zapewnienia bezpieczeństwa danym. Często jednak ustawy szczególne określone kwestie albo pomijają, albo odrębnie regulują $z$ uwagi na ich specyfikę, co sprawia trudności w ocenie tego, czy dana regulacja obniża czy podwyższa ów standard ochronny. Odnosząc się do prezentowanego zagadnienia, wskazać należy, że przepis art. 26 ust. 3 u.p.p., przewidujący dostęp do dokumentacji medycznej różnego rodzaju podmiotów prawa ma charakter porządkujący ${ }^{60}$. Wymienione $\mathrm{w}$ przepisie podmioty są $z$ reguły uprawnione do przetwarzania danych medycznych na podstawie odrębnych aktów prawnych. Wystąpienie z żądaniem udostępnienia dokumentacji medycznej wymaga wskazania przez nie podstaw prawnych, które zwykle uzasadniają realizację tzw. istotnych interesów publicznych ${ }^{61}$. Ponieważ podmiot leczniczy jest administratorem danych osobowych i to on udostępnia dane, wskazana wyżej regulacja nie mogła objąć omawianego przypadku. Ustawodawca bowiem uregulował odrębnie cele przetwarzania danych przez podmiot nimi administrujący, i to zarówno w ustawie o prawach pacjenta (por. art. 23-24 u.p.p.), jak i w ustawie o ochronie danych osobowych (por. art. 27 ust. 2 pkt 7 u.o.d.o.). Z tych też względów, argumentacja SA, opierająca się na zastosowaniu reguły lex specialis derogat legi generali, jest nieprawidłowa. Norma szczegółowa nie opisuje bowiem sytuacji udostępniania dokumentacji medycznej na potrzeby ochrony praw podmiotu przetwarzającego dokumentację.

Warto w tym miejscu odwołać się także do argumentacji prezentowanej w sytuacji kolizji pomiędzy ochroną sfery tajemnicy pacjenta a interesem lekarza. Jak się wskazuje, konflikt tego typu interesów ma miejsce przy dochodzeniu roszczeń przez lekarza z tytułu należnego mu honorarium od pacjenta czy w razie obrony przed zarzutami mu stawianymi, zagrażającymi jego reputacji zawodowej ${ }^{62}$. W takich przypadkach nie można zaakceptować wyłączenia prawa do obrony lekarza, byłoby to bowiem nadużycie praw ze strony osoby domagającej się respektu dla tajemnicy ${ }^{63}$. Argumentację tę możemy, jak się wydaje, odnieść do prezentowanej tu kolizji pomiędzy ochroną danych zawartych w dokumentacji medycznej a potrzebą wykorzystania

59 Zob. U. Drozdowska, (w:) Tworzenie..., op. cit., s. 32-33.

60 D. Karkowska, Ustawa o prawach pacjenta i Rzeczniku Praw Pacjenta. Komentarz, Warszawa 2012, wyd. 2, s. 372.

61 Przesłanka tzw. istotnego interesu publicznego jest wyrażona m.in. w art. 8 ust. 2 Europejskiej Konwencji o ochronie praw człowieka i podstawowych wolności z dnia 4 listopada 1950 r. (Dz.U. z 1993 r. Nr 61, poz. 284), której Polska jest stroną. Na tle tego przepisu wskazuje się w orzecznictwie ETPCz na możliwe w prawie krajowym ograniczenia prawa do ochrony danych medycznych w sytuacji: konieczności zapewnienia bezpieczeństwa publicznego, dobrobytu gospodarczego kraju, ochrony porządku i zapobiegania przestępstwom, ochrony zdrowia i moralności, ochrony praw i wolności osób. Zob. też treść art. 31 ust. 3 Konstytucji RP, dotyczącego ograniczeń praw i wolności.

62 M. Safjan, Prawo i medycyna. Ochrona praw jednostki a dylematy współczesnej medycyny, Warszawa 1998, s. 147.

63 Ibidem. 
tych danych dla obrony podmiotu leczniczego. Za nadużycie prawa należy uznać pozbawienie możliwości wykorzystania dokumentacji medycznej celem obrony przed odpowiedzialnością odszkodowawczą. W tej sytuacji podmiot leczniczy nie powinien być narażony na zarzut bezprawności postępowania.

Warto uzupełniająco wskazać, że problem ten został dostrzeżony przez ustawodawcę unijnego, który w przepisie art. 9 ust. 2 pkt f) rozporządzenia Parlamentu i Rady UE z dnia 27 kwietnia 2016 r. (2016/679) w sprawie ochrony osób fizycznych w związku z przetwarzaniem danych osobowych i w sprawie swobodnego przepływu takich danych oraz uchylenia dyrektywy $95 / 46 / \mathrm{WE}^{64}$ uznał przetwarzanie danych wrażliwych za dozwolone, o ile jest to niezbędne do ustalenia, dochodzenia lub obrony roszczeń lub w ramach sprawowania wymiaru sprawiedliwości przez sądy.

Przechodząc do argumentu Sądu Apelacyjnego, że opinia prywatna nie ma waloru dowodowego, ponieważ stronie przysługuje prawo złożenia wniosku o dopuszczenie dowodu z opinii biegłego, należy wskazać, iż stoi on w sprzeczności z prezentowaną w punkcie drugim linią orzeczniczą. Walor dowodowy opinii prywatnej należy upatrywać $\mathrm{w}$ tym, że może stać się ona dokumentem prywatnym, a rolą sądu jest wzięcie pod uwagę argumentacji w niej przedstawionej i skonfrontowanie jej z tą prezentowaną przez biegłego sądowego. Punkt widzenia Sądu Apelacyjnego w Krakowie prowadzi do naruszenia zasady „równości broni” w postępowaniu cywilnym, pacjent bowiem może skorzystać z opinii prywatnej, podmiot leczniczy - zaś nie. W kontekście zasady procesowej, oznaczającej równość środków procesowych dla każdej ze stron procesu ${ }^{65}$, zauważyć można potrzebę uregulowania w ustawie procesowej zagadnień związanych z wykorzystaniem opinii prywatnej ${ }^{66}$.

Na marginesie rozważań warto dodać, że sądy administracyjne nie zajmują tak rygorystycznego stanowiska, jak sądy cywilne w przedmiocie wykorzystania dokumentacji dla celów prowadzonego postępowania ${ }^{67}$. W wyroku NSA z dnia 25 sierpnia $2011 \mathrm{r}^{68}{ }^{6 z y t a m y, ~ z ̇ e ~ t r e s ́ c ́ ~ d o k u m e n t a c j i ~ m e d y c z n e j ~ s t a n o w i ~ p o d s t a w e ̨ ~ d l a ~ u s t a l e n i a ~}$ istotnej okoliczności sprawy (w tym wypadku chodziło o ustalenie choroby zawodowej) i nie można podzielić stanowiska strony o braku możliwości zapoznania się (przez organ administracyjny) z jej treścią. To bowiem spowodowałoby wydanie de-

Dz.U. UE L. 119/1, http://eur-lex.europa.eu/legal-content/PL/TXT/?uri=CELex:32016R0679 (tzw. ogólne rozporządzenie o ochronie danych). Rozporządzenie wprowadza jednolitą regulację prawną dotyczącą ochrony danych osobowych na poziomie UE. Wskazana regulacja będzie obowiązywała na terenie państw UE w sposób bezpośredni (bez potrzeby implementowania) począwszy od dnia 25 maja $2018 \mathrm{r}$.

65 Zob. A. Góra-Błaszczykowska, Zasada równości stron w procesie cywilnym, Warszawa 2008, s. 90 i n.

66 Rozwiązaniem jest wprowadzenie instytucji biegłego-strony, która wpisuje się w zasadę kontradyktoryjności sporu, ewentualnie instytucji świadka - biegłego. Można także próbować tworzyć dodatkowe mechanizmy prawne służące kontroli rzetelności przedstawionych prywatnych opinii. Nie ma jednak tu miejsca na szersze zaprezentowanie tych propozycji. Zob. w piśmiennictwie wywody A. Klich, Dowód, op. cit., s. 89-93.

67 Zob. wyrok WSA w Warszawie z dnia 5 sierpnia 2005 r., II SA/Wa 564/05, Legalis; wyrok WSA w Rzeszowie z dnia 24 lutego 2011 r., II SA/Rz 981/10, Legalis; wyrok WSA we Wrocławiu z dnia 28 lutego 2013 r., IV SA/Wr 695/12, Legalis; wyrok WSA w Warszawie z dnia 18 grudnia 2013 r., II SA/Wa 1449/13, Lex nr 1542378. Decydujące znaczenie dla tej linii orzeczniczej ma zasada wewnętrznej jawności postępowania. Sygn. II OSK 991/11, Legalis. Zob. także R. Kubiak, Tajemnica medyczna, op. cit., s. 228-229. 
Dopuszczalność wykorzystania tzw. opinii prywatnych w cywilnych procesach...

cyzji, która nie podlegałaby żadnej kontroli, skoro jedynym dowodem leżącym u jej podstaw może okazać się orzeczenie właściwej jednostki orzeczniczej, którego nie da się zweryfikować i porównać z materiałem źródłowym, który legł u podstaw jego wydania. Podobnie w sprawie rozstrzyganej przez WSA w Warszawie w wyroku z dnia 5 sierpnia 2005 r. ${ }^{69}$ Podmiotem, który miał dostęp do dokumentacji medycznej pokrzywdzonego w postępowaniu przygotowawczym, był pełnomocnik oskarżonego, on też przekazał ją wydającemu opinię prywatną lekarzowi. W tej sytuacji WSA przyjął możliwość zastosowania art. 27 ust. 2 pkt 5 u.o.d.o. i uznał, że nie doszło do naruszenia prawa.

\section{Wnioski końcowe}

Opinia prywatna w procesach medycznych nie ma takiego znaczenia jak dowód $\mathrm{z}$ opinii biegłego w rozumieniu art. $278 \$ 1 \mathrm{kpc}$. Ekspertyzy te są zwykle negowane przez stronę przeciwną, która zarzuca im brak wiarygodności oraz obiektywizmu, przede wszystkim ze względu na odpłatny ich charakter. Tym niemniej ich rola w procesach cywilnych stale wzrasta. Jest to spowodowane przede wszystkim kryzysem instytucji biegłych sądowych. Na opinie biegłych sądy czekają od kilku miesięcy do kilku lat ${ }^{70}$. Ponadto brakuje biegłych $\mathrm{w}$ wielu specjalnościach, a niektórzy $\mathrm{z}$ nich ze względu na liczne obowiązki zawodowe odmawiają wykonania opinii na użytek sądu. Alternatywy nie zapewniają opinie instytutów naukowo-badawczych, ponieważ te także wyznaczają bardzo odległe terminy celem ich sporządzenia ${ }^{71}$. Istniejące rozwiązania prawne umożliwiają tylko w części wykorzystanie prywatnych opinii biegłych dla dobra wymiaru sprawiedliwości, nie mogą one bowiem konkurować $\mathrm{z}$ dowodem $\mathrm{z}$ opinii biegłego sądowego.

Interpretacja przepisów prawa materialnego z zakresu ochrony danych osobowych nie powinna prowadzić do tworzenia dodatkowych barier uniemożliwiających wykorzystanie tego środka dowodowego w procesie cywilnym. Prowadzi to bowiem do tzw. wykluczenia prawnego. Istotą tego typu wykluczenia - jak wskazuje K. Flaga-Gieruszyńska - jest całkowite pozbawienie bądź znaczące ograniczenie możliwości korzystania przez określone osoby lub całe zbiorowości z przynależnych im praw i wolności, a także kompetencji ${ }^{72}$. Przyzwyczailiśmy się do tego, że tego typu wykluczenie dotyczy pacjenta, jako strony (z definicji) słabszej w stosunkach profesjonalnych, zwłaszcza w relacji pacjent - zorganizowana instytucja medyczna. Tymczasem rzeczywistość bywa różna, zdarzają się podmioty lecznicze o bardzo złej

II SA/Wa 564/05, Legalis.

Zob. J. Budzowska, Opinia prywatna, op. cit., s. 279.

Zob. A. Przybycień, P. Szewczyk, Terra incognita, czyli o alternatywnym sposobie kompensacji szkód medycznych, „Edukacja Prawnicza” 2012, nr 1, dodatek specjalny, s. VIII.

72 K. Flaga-Gieruszyńska, The problem of legal exclusion on the example of access to justice in civile cases, (w:) M. Sitek, G. Damacco, A. Ukleja, M. Wójcicka (red.), Europe and Founding Fathers. Investment in common future, Olsztyn 2013, s. 125. 
kondycji finansowej, które mogą mieć problem nie tylko z wypłatą świadczeń, ale i z poniesieniem kosztów długotrwałego procesu sądowego. Kwestii tej nie rozwiązuje ubezpieczenie od odpowiedzialności cywilnej, ponieważ ubezpieczyciele zwykle nie chcą wypłacać świadczeń zanim nie zapadnie wyrok sądu. W myśl zatem zasady równości broni należy wyposażyć każdą ze stron w możliwość rzetelnego zaprezentowania swojego stanowiska, w tym zgłaszania wniosków dowodowych i przedstawiania dowodów, w okolicznościach, które nie sytuują jej w sytuacji gorszej w stosunku do przeciwnika procesowego ${ }^{73}$.

\section{BIBLIOGRAFIA}

Barta J., Fajgielski P., Markiewicz R., Ochrona danych osobowych, Komentarz, Kraków 2004.

Barta P., Litwiński P., Ustawa o ochronie danych osobowych. Komentarz, wyd. 3, Warszawa 2015.

Bączyk-Rozwadowska K., Błąd lekarski w świetle doktryny i orzecznictwa sądowego, „Prawo i Medycyna" 2008 , nr 3.

Budzowska J., Opinia prywatna w sprawie o tzw. błąd medyczny, „Monitor Prawniczy” 2012, nr 5.

Byrski J., Wybrane tajemnice zawodowe a prawna ochrona danych osobowych, (w:) G. Sibiga, X. Konarski (red.), Ochrona danych osobowych. Aktualne problemy i nowe wyzwania, Warszawa 2007.

Drozdowska U., Kowalewska-Borys E., Wojtal. W., Bieliński A., (w:) U. Drozdowska (red.), Dokumentacja medyczna, Warszawa 2012.

Flaga-Gieruszyńska K., The problem of legal exclusion on the example of access to justice in civile cases, (w:) M. Sitek, G. Damacco, A. Ukleja, M. Wójcicka (red.), Europe and Founding Fathers. Investment in common future, Olsztyn 2013.

Gajda-Roszczynialska K., (w:) Ł. Błaszczyk, K. Markiewicz (red.), Dowody i postępowanie dowodowe w sprawach cywilnych. Komentarz praktyczny z orzecznictwem, Warszawa 2015.

Girdwoyń P., Tomaszewski T., Opinie biegłych w sprawach medycznych na tle zasady kontradyktoryjności, (w:) Prawo wobec problemów społecznych. Księga Jubileuszowa Profesor Eleonory Zielińskiej, Warszawa 2016.

Góra-Błaszczykowska A., Zasada równości stron w procesie cywilnym, Warszawa 2008.

Jagiełło D., Dowód z opinii prywatnej w świetle procedury cywilnej oraz karnej, „Themis Polska Nova” 2015, nr 2 (9).

Janiszewska B., Aktualne zagadnienia procesów lekarskich (przegląd orzecznictwa), „Prawo i Medycyna" 2004, nr 1.

Janiszewska B., Dowodzenie w procesach lekarskich (domniemania faktyczne i dowód prima facie, „Prawo i Medycyna” 2004, nr 2.

Karkowska D., Ustawa o prawach pacjenta i Rzeczniku Praw Pacjenta. Komentarz, Warszawa 2012.

Klich A., Dowód z opinii biegłego w postępowaniu cywilnym. Biegły lekarz, Warszawa 2016.

73 A. Góra-Błaszczykowska, Zasada równości stron, op. cit., s. 90. 
Klich A., Lekarz jako osobowe źródło dowodowe w postępowaniu cywilnym (część I - lekarz jako świadek), „Prawo i Medycyna” 2013, nr 3-4.

Knoppek K., Prywatna opinia biegłego de lege lata i de lege ferenda, (w:) K. Flaga-Gieruszyńska, G. Jędrejek (red.), Aequitas segitur legem. Księga Jubileuszowa z okazji 75-lecia urodzin profesora Andrzeja Zielińskiego, Warszawa 2014.

Kubiak R., Tajemnica medyczna, Warszawa 2016.

Kwiatkowski Z., Dopuszczalność wykorzystania „opinii prywatnej” w procesie karnym, (w:) A. Przyborowska-Klimczak, A. Taracha (red.) Iudicum et scientia. Księga Jubileuszowa Profesora Romualda Kmieciaka, Warszawa 2001.

Misztal-Konecka J., Znaczenie tzw. opinii prywatnej dla postępowania cywilnego, „Monitor Prawniczy” 2013, nr 2.

Piasecki K., System dowodów i postępowanie dowodowe w sprawach cywilnych, Warszawa 2010.

Podemska A., Opinia biegłego w nowym modelu postępowania karnego, „Zeszyty Naukowe Towarzystwa Doktorantów UJ. Nauki Społeczne” 2014, nr 8.

Przybycień A., Szewczyk P., Terra incognita, czyli o alternatywnym sposobie kompensacji szkód medycznych, „Edukacja Prawnicza” 2012, nr 1, dodatek specjalny.

Rogowski M., Trudności związane z przeprowadzeniem dowodu w procesach lekarskich, (w:) J. Haberko, R.D. Kocyłowski, B. Pawelczyk (red), Lege artis. Problemy prawa medycznego, Poznań 2008 .

Safjan M., Prawo i medycyna. Ochrona praw jednostki a dylematy współczesnej medycyny, Warszawa 1998.

Sieńko A., Błędy medyczne, odpowiedzialność lekarza i placówki medycznej. Jak uniknąć kosztownych pułapek, wyd. 2, Warszawa 2013.

Szymańska A., Wykorzystanie prywatnej ekspertyzy w postępowaniu karnym, „Studenckie Zeszyty Naukowe" 2014, nr 25.

Woźniewski K., Tzw. prywatne opinie biegłych, „Gdańskie Studia Prawnicze - Przegląd Orzecznictwa” 2005, nr 3 . 